\title{
PENGARUH MODEL PEMBELAJARAN INQUIRY TRAINING TERHADAP HASIL BELAJAR FISIKA SISWA
}

\author{
Purwanto $^{1}$ dan Arini Ulfah Mawaddah ${ }^{2}$ \\ 1.Dosen Fisika Unimed \\ 2.Mahasiswa Pendidikan Fisika Unimed
}

\begin{abstract}
ABSTRAK
Penelitian ini bertujuan untuk mengetahui pengaruh model pembelajaran Inquiry TrainingJenis penelitian ini adalah quasi eksperimen. Populasi dalam penelitian adalah seluruh siswa kelas VII MTs Aisyiyah Medan T.P 2014/2015yang terdiri dari 3 kelas. Pengambilan sampel dilakukan dengan cara simple random sampling Dari hasil penelitian diperoleh nilai rata-rata pretes kelas eksperimen 47,75 dan nilai rata-rata kelas kontrol 47,42.Sebelum dilakukan model pembelajaran berbasis masalah menggunakan media petakonsep, kemampuan awal kedua kelompok siswa sama.Setelah model pembelajaran selesai diberikan, diperoleh postes dengan hasil rata-rata kelas eksperimen75,85dan kelas kontrol 63,28. Data pretes dan postes telah memenuhi uji prasyarat, yaitu uji normalitas dan homogenitas dengan taraf signifikansi $\alpha=0,05$, sehingga hasil uji t pretes memiliki kesamaan rata-rata dan uji $\mathrm{t}$ postes menyatakan ada perbedaan akibat pengaruh model pembelajaran Inquiry Training terhadap hasil belajar fisika siswa.Selain berpengaruh terhadap hasil belajar siswa, model pembelajaran Inquiry Training juga meningkatkan aktivitas belajar siswa yang dapat diamati dengan peningkatan aktivitas dari pertemuan pertama sampai pertemuan kedua .Dari hasilpengamatan yang dilakukanoleh observer, diperoleh bahwa rata-rata peningkatan aktivitas siswa cukup baik dari pertemuan I dengan kategori cukup aktif ke pertemuan II dengan kategori aktif.
\end{abstract}

Kata Kunci : Pengaruh, Inquiry Training, , Hasil Belajar

\section{PENDAHULUAN}

Era globalisasi dan teknologi informasi merupakan fakta yang tak dapat di pungkiri bahwa telah terjadi perubahan yang sangat cepat, dramatis, dan kompetatif dalam berbagai bidang kehidupan.Ada banyak sains yang dikembangkan manusia dewasa ini salah satunya adalah fisika.Oleh karena itu penguasaan terhadap fisika sangat diperlukan.

Pelajaran IPA (Sains) merupakan salah satu mata pelajaran yang diberikan pada setiap jenjang pendidikan dan Perguruan Tinggi. Fisika merupakan bagian dari Sains atau IPA yang mempelajari fenomena dan gejala alam secara empiris, logis, dan rasional yang melibatkan proses dan sikap ilmiah.

Fisika merupakan mata pelajaran yang mengharuskan siswa memahami, mengerti serta mengaplikasikannya dalam kehidupan nyata.Selama ini siswa hanya terpaku pada langkah-langkah penyelesaian yang diberikan guru, siswa beranggapan bahwa jawaban guru yang paling benar, sehingga siswa merasa takut mengemukakan ide atau pendapatnya.

Menurut Sanjaya (2009) "salah satu masalah yang dihadapi dunia pendidikan adalah masalah lemahnya proses pembelajaran".Dalam proses pembelajaran, anak kurang didorong untuk mengembangkan kemampuan 
berpikir. Proses pembelajaran di dalam kelas diarahkan kepada kemampuan anak untuk menghafal informasi, otak anak dipaksa untuk mengingat dan menimbun berbagai informasi yang diingatnya itu untuk menghubungkannya dengan kehidupan sehari-hari.

Berdasarkan hasil studi pendahuluan di Madrasah Tsanawiyah Swasta (MTs) Aisiyyah, atau setara dengan dengan Sekolah Menengah Pertama dengan instrumen observasi angket dan wawancarayang disebarkan ke 35 orang siswa MTs Aisiyyah diperoleh, 62,9\% (22 orang siswa) berpendapat fisika adalah pelajaran yang sulit dipahami, dan kurang menarik. $25,7 \%$ (9 orang siswa) berpendapat fisika biasa-biasa saja, dan hanya 11,4\% (4 orang siswa) yang berpendapat fisika menyenangkan dan mudah dimengerti.

Data angket juga menunjukkan bahwa sebanyak $31,4 \%$ (11 orang siswa) menyatakan mereka senang mengerjakan soal-soal fisika apabila dilakukan dengan cara berdiskusi atau berkelompok. Serta sebanyak $65,7 \%$ (23 orang siswa) tidak pernah mengemukakan pendapatnya pada saat pelajaran fisika berlangsung, sehingga akibatnya proses belajar mengajar hanya terpaku pada guru saja dan membuat siswa menjadi pasif. $\mathrm{Hal}$ ini disebabkan model pembelajaran yang digunakan oleh guru kurang bervariasi.

Selanjutnya penulis melakukan wawancara diMTs Aisiyyah dengan guru fisika, hasil belajar siswa pada mata pelajaran fisika masih tergolong rendah. Kesimpulan ini ditarik dari nilai ujian fisika yang dicapai siswa rata-rata masih dibawah Kriteria Ketuntasan Minimum (KKM) yakni dibawah 75, mengingat KKM di sekolah itu adalah 75 Hal ini disebabkan oleh metode mengajar fisika yang disajikan kurang tepat sehingga kurang menarik minat siswa untuk belajar fisika. Berdasarkan hasil angket, dan wawancara dengan guru dan beberapa orang siswa di MTs Aisiyyah

Medan diketahui bahwa metode mengajar yang sering dilakukan adalah ceramah, mencatat, dan mengerjakan soal.

Pada kenyataannya, siswa menginginkan guru mengajar dengan metode yang lebih bervariasi sehingga siswa dapat belajar dengan suasana yang menyenangkan dan mengasyikkan. Siswa juga mengharapkan suasana kelas yang lebih rileks dan tidak kaku. Maka itu, menurut Sagala (2009) bahwa "Guru perlu memiliki pengetahuan tentang pendekatan dan teknik-teknik mengajar yang baik dan tepat sehingga kegiatan belajar yang efektif dan efisien dapat berlangsung sesuai tujuan yang diharapkan".

Berdasarkan hasil wawancara dengan guru fisika di kelas VII MTs Aisiyyah,mengatakan dalam melaksanakan pembelajaran beliau masih menggunakan pembelajaran konvensional. Pola mengajar yang digunakan masih menggunakan metode ceramah, mencatat dan mengerjakan soal sehingga kurang variatif dan siswa benjadi tidak aktif dalam proses pembelajaran, sehingga hasil belajar masih dibawah standart kelulusan, dimana hanya $40 \%$ siswa yang memiliki nilai $\geq 75$, sedangkan $60 \%$ selebihnya memiliki nilai fisika $<75$.

Untuk mengatasi permasalahan di atas perlu diupayakan pemecahannya, yaitu dengan menggunakan model pembelajaran yang lebih efektif, yang dapat meningkatkan minat, semangat, kemampuan dan kemampuan berpikir untuk dapat bekerja bersama teman dalam menemukan suatu permasalahan, dan kegembiraan siswa serta dengan sendirinya diharapkan dapat meningkatkan hasil belajar siswa.

Adapun model pembelajaran
yang perlu dikembangkan yang
diharapkan dapat meningkatkan hasil
belajar siswa melalui penerapan
peningkatan berpikir unutk memecahkan


masalah, menemukan sesuatu untuk dirinya dan terus mengasah kemampuan berpikir melalui peristiwa-perstiwa yang terjadi dalam kehidupan sehari-hari yang berhubungan dengan konsep fisika.

Berdasarkan pemaparan masalah di atas, salah satu cara yang dapat dilakukan untuk meningkatkan hasil belajar dan proses pembelajaran fisika serta meningkatkan kemampuan berpikir siswa, pada siswa kelas VII MTs Aisiyyah adalah dengan menerapkan model pembelajaran Inquiry Training.

Menurut Joyce dkk (2011) untuk menyingkapi masalah di atas, perlu adanya upaya yang dilakukan oleh guru untuk membuat siswa lebih tertarik mempelajari fisika, mengingat bahwa proses pembelajaran fisika merupakan proses pembelajaran untuk membuktikan sesuatu yang masih teori. Perlu diterapkan model pembelajaran dari fakta menuju teori atau from facts to teories.

Pembenahan dengan menerapkan model pembelajaran Inquiry Training, permasalahan tersebut diharapkan dapat teratasi. Hal ini didasarkan karena model pembelajaran Inquiry Training ini diarahkan untuk mengajarkan siswa dalam proses mengkaji dan menjelaskan suatu fenomena khusus. Tujuannya adalah membantu

mengembangkan keterampilan intelektual yang diperlukan untuk mengajukan pertanyaan dan menemukan jawabannya berdasarkan rasa ingin tahunya.

Melalui model pembelajaran inquiry training ini siswa diharapkan aktif mengajukan pertanyaan mengapa sesuatu terjadi kemudian mencari dan mengumpulkan serta memproses data secara logis untuk selanjutnya mengembangkan strategi intelektual yang dapat digunakan untuk menemukan jawaban atas pertanyaan mengapa sesuatu terjadi. Inquiry Training dimulai dengan menyajikan peristiwa yang mengandung teka-teki atau pengetahuanbersifattentative (tidak pasti) kepada siswa.

Salah satu konsep yang membutuhkan keterlibatan siswa dalam berbagai aktivitas dan membuat siswa lebih aktif adalah konsepkalor dan perpindahan kalor. Dimana pada konsep kalor dan perpindahan kalor siswa dihadapkan pada suatu permasalahan yang terjadi dalam kehidupan seharihari. Seperti pada permasalahan bagaimana api membengkokkan strip logam. Dalam hal ini siswa mulai menyelidikinya lebih dalam.Awalnya siswa hanya berpikir, bahwa biasanya, benda yang dipanaskan tidak bengkok, tetapi mungkin terbakar.Lalu mengapa logam tersebut justru membengkok saat dipanaskan? Hal tersebut mulai menunjukkan peristiwa yang aneh, tetapi siswa tidak bisa menyimpulkan begitu saja, mereka harus bekerja menjelaskan situasi, dan hasil dari kerja ini akan berbentuk wawasan, konsep, dan teori baru bagi mereka.

Siswa-siswa yang menghadapi situasi tersebut akan termotivasi menemukan jawaban masalah-masalah yang masih menjadi teka-teki. Hal ini sesuai dengan teori Suchman dalam Joyce dkk (2011) yang menerapkan model pembelajaran dari fakta menuju teori ataufrom facts to teories. Selain itu, guru juga dapat menggunakan kesempatan ini untuk mengajarkan prosedur pengkajian sesuai dengan langkah-langkah pembelajaran Inquiry Training.

Penerapan Model pembelajaran Inquiry Training ini sudah pernah diteliti oleh beberapa peneliti sebelumnya, seperti: Syafitri (2014) dengan judul "Pengaruh Model Pembelajaran Inquiry Training Terhadap Hasil Belajar Siswa Pada Materi Kalor Kelas X Semester II SMA Negeri 1 Tanjung Pura T.P. 2013/2014". Dari hasil analisis data diperoleh nilai rata-rata pretes 40,4 dan 
setelah diberi perlakuan yaitu model InquiryTraining maka hasil belajar siswa meningkat dengan nilai rata-rata postest 75,6 . Sementara hasil belajar fisika siswa dengan pembelajaran konvensional memiliki nilai rata-rata pretest 40,1 dan postest 60,3. Tetapi selain terdapat peningkatan yang signifikan peneliti belum dapat memanfaatkan waktu secara efisien dalam menerapkan model Inquiry Training ini, oleh karena itu bagi peneliti selanjutnya yang ingin menerapkan model Inquiry Training ini sebaiknya telah mempersiapkan model ini dengan sebaiknya sehingga dapat menggunakan waktu secara maksimal.

Penelitian selanjutnya dilakukan oleh Marwan (2014) dengan judul “ Pengaruh Model pembelajaran Inquiry Training Terhadap Hasil Belajar Siswa Pada Materi Suhu dan Kalor Kelas X Semester II SMA Negeri 1 Batang Kuis T.P. 2013/2014". Dari hasil analisis data diperoleh nilai rata-rata pretes 35,16 dan setelah diberi perlakuan yaitu model InquiryTraining maka hasil belajar siswa meningkat dengan nilai rata-rata postes 74,19. Sementara hasil belajar fisika siswa dengan pembelajaran konvensional memiliki nilai rata-rata pretest 34,03 dan postest 67,90 .

Berdasarkan uraian diatas hasil penelitian yang dilakukan oleh peneliti sebelumnya dan hasil observasi maka peneliti tertarik melakukan penelitian dengan perbedaan materi, tempat penelitian, dan peneliti akan mencoba menutupi kelemahan dari penelitian sebelumnya yang bertujuan untuk meningkatkan hasil belajar fisika siswa dengan mengangkat judul "Pengaruh Model Pembelajaran Inquiry TrainingTerhadap Hasil Belajar Fisika Siswa Pada Materi Pokok Kalor dan Perpindahan Kalor Di Kelas VII MTs Aisiyyah Medan T.P 2014/2015"

\section{METODE PENELITIAN}

Penelitian ini telah dilaksanakan di MTs Swasta Aisiyyah Medan kelas VII yang beralamat di Jl. Masjid No. 806 Bandar Khalifah Kec. Percut Sei Tuan Kabupaten Deli Serdang dan telah dilaksanakan pada semester II T.P. 2014/2015. Waktu penelitian 4 bulan terhitung Mulai Februari hingga Juni 2015 .

populasi dalam penelitian ini adalah seluruh siswa kelas VII semester II MTs Aisiyyah Medan T.P. 2014/2015 yang terdiri dari 3 kelas yang berjumlah 96 orang yaitu kelas VII-A hingga VII-C

Dengan menggunakan teknik sampel kelas (simple random sampling), sampel diambil dari populasi yaitu sebanyak 2 kelas. Satu kelas dijadikan sebagai kelas ekperimen yaitu kelas VIIA yang diajarkan dengan model pembelajaran Inquiry Training dan satu kelas tagi dijadikan sebagai kelas kontrol yaitu kelas VII-B yang diajar dengan pembelajaran konvensional.

Jenis penelitian yang digunakan adalah quasi eksperiment, yaitu penelitian yang dimaksudkan untuk mengetahui ada tidaknya akibat dari sesuatu yang dikenakan pada objek penelitian yaitu siswa. Penelitian ini melibatkan dua kelas yaitu kelas eksperimen dan kelas kontrol. Kedua kelas ini mendapat perlakuan yang berbeda-beda, kelas eksperimen diberi model pembelajaran Inquiry Training sedangkan kelas kontrol diberi model pembelajaran konvensional

Penelitian termasuk jenis penelitian quasi eksperiment yang bertujuan untuk melihat atau mengetahui ada tidaknya perbedaan akibat dari sesuatu yang dikenakan pada subjek yaitu siswa. Dengan memberi perlakuan pada kelompok sampel penelitian yang dilakukan melalui model pembelajaran Inquiry Training.

Penelitian ini melibatkan dua kelas yang diberi perlakuan yang 
berbeda. Untuk mengetahui hasil belajar siswa dilakukan dengan memberikan tes pada kedua kelas sebelum dan sesudah diberikan perlakuan. Rancangan penelitian ini sebagai berikut: (Arikunto, 2008)

Tabel 3.1.Desain Penelitian (Two Group Pretes PostesDesign)

\begin{tabular}{|c|c|c|c|}
\hline Kelas & Pretes & Perlakuan & Postes \\
\hline Eksperimen & $\mathrm{X}_{1}$ & $\mu_{1}$ & $\mathrm{X}_{2}$ \\
\hline Kontrol & $\mathrm{X}_{1}$ & $\mu_{2}$ & $\mathrm{X}_{2}$ \\
\hline
\end{tabular}

Keterangan :

$\mathrm{X}_{1}=$ Pemberian pretes.

$\mathrm{X}_{2}=$ Pemberian postes.

$\mu_{1}=$ Perlakuan dengan model pembelajaran Inquiry Training

$\mu_{2}=$ Perlakuan dengan model pembelajaran konvensional.

Uji Hipotesis

Pengujian hipotesis dilakukan dengan dua cara yaitu :

1. Uji kemampuan awal atau pretes siswa (uji t dua pihak)

Uji t dua pihak digunakan untuk mengetahui kesamaan kemampuan awal siswa pada kedua kelompok sampel. Hipotesis yang diuji berbentuk :

Ho : $\mu_{1}=\mu_{2}:$ kelas eksperimen dan kelas kontrol mempunyai kemampuan awal yang sama

$\mathrm{H}_{1}: \mu_{1} \neq \mu_{2}:$ kelas eksperimen dan kelas

kontrol mempunyai kemampuan awal yang berbeda

Bila data penelitian berdistribusi normal dan homogen maka untuk menguji hipotesis menggunakan uji beda dengan rumus :

$$
\mathrm{t}_{\text {hitung }}=\frac{\overline{X_{1}}-\overline{X_{2}}}{S \sqrt{\left(\frac{1}{n_{2}}\right)+\left(\frac{1}{n_{2}}\right)}}
$$

Tetapi jika kedua kelas tidak homogen, maka digunakan :

$$
t^{\prime}=\frac{\overline{X_{1}}-\overline{X_{2}}}{S \sqrt{\frac{S_{1}^{2}}{n_{1}}+\frac{S_{2}^{2}}{n_{2}}}}
$$

(Sudjana, 2005)

Di mana $S$ adalah varians gabungan yang dihitung dengan rumus:

$$
\mathrm{S}^{2}=\frac{\left(n_{1}-1\right) S_{1}^{2}+\left(n_{2}-1\right) S_{2}^{2}}{n_{1}+n_{2}-2}
$$

Dengan $\mathrm{t}=$ distribusi $\mathrm{t} ; \bar{x}_{1}=$ nilai rata rata kelas eksperimen; $\quad \bar{x}_{2}=$ nilai rata rata kelas kontrol; $\quad \mathrm{n}_{1}=$ ukuran kelas eksperimen; $\mathrm{n}_{2}=$ ukuran kelas kontrol; $\mathrm{S}_{1}^{2}=$ varians kelas eksperimen; $\mathrm{S}_{2}^{2}=$ varians kelas kontrol.

Kriteria pengujian adalah Ho diterima jika $-t_{1-1 / 2 \alpha}<t<t_{1-1 / 2 \alpha}$ dimana $t_{1}-1 / 2 \alpha$ didapat dari daftar distribusi $t$ dengan $\mathrm{dk}=\left(n_{1}+n_{2}-2\right)$ dan peluang ( 1-1/2 $\alpha$ ) dan $\alpha=0,05$. Untuk harga $\mathrm{t}$ lainnya Ho ditolak (Sudjana, 2005).

b. Uji Kemampuan Postest (Uji t satu pihak)

Uji t satu pihak digunakan untuk mengetahui efek atau pengaruh dari suatu perlakuan yaitu model pembelajaran peningkatan kemampuan berpikir terhadap hasil belajar siswa pada materi pokok kaor dan perpindahan kalor.

Hipotesis yang diujikan adalah:

$\mathrm{H}_{0}: \mu_{1} \leq \mu_{2}$ : hasil belajar siswa pada materi pokok kalor dan perpindahan kalor dengan model pembelajaran Inquiry Trainingtidak lebih 


baik daripada model
pembelajaran
konvensional
hasil belajar siswa pada
materi pokok kalor dan
perpindahan kalor
dengan

Hasil uji normalitas, homogenitas dan kesamaan rata-rata pretes ditunjukkan pada Tabel 2.

Tabel 3. Hasil Uji Normalitas, Homogenitas dan Hipotesis Siswa

Tabel 2. Hasil Uji Normalitas, Homogenitas dan Kesamaan Rata-rata Pretes

Berdasarkan Tabel 2 data pretes kedua kelas normal, homogen dan tidak ada perbedaan secara signifikan, maka pada kedua kelas sampel diberikan perlakuan yang berbeda, pada kelas eksperimen diberikan perlakuan dengan
Berdasarkan Tabel 3 diperoleh bahwa data postes kedua kelas normal, homogen dan nilai $t_{\text {hitung }}>t_{\text {tabel }}$ yaitu $2,68>1,66$, sehingga dapat disimpulkan bahwa ada perbedaaan yang signifikan akibat pengaruh penerapan model pembelajaran problem based learning menggunakan peta konsep terhadap hasil belajar siswa. 
perkembangan aktivitas siswa dikelas eksperimen mengalami peningkatan selama pembelajaran dengan menggunakan model pembelajaran problem based learning menggunakan peta konsep yaitu nilai rata-rata aktivitas belajar siswa dipertemuan I yaitu, $56,46 \%$, pertemuan II rata-rata $74,94 \%$, serta pertemuan III $86,95 \%$. Hal ini menunjukkan bahwa model pembelajaran problem based learning menggunakan peta konsep tidak hanya meningkatkan hasil belajar siswa saja, tetapi juga dapat meningkatkan aktivitas siswa.

KESIMPULAN

Berdasarkanhasilpenelitian diperolehmakadapatdisimpulkan:

1. Hasilbelajarsiswamenggunakan model pembelajaranInquiry Trainingpada materi pokok Kalor dan Perpindahan Kalor kelas VII di MTs Aisyiyah diperoleh nilai rata-rata kelas dengan kategori tuntas.

2. Hasilbelajarsiswamenggunakanp embelajaran konvensional pada materi pokok Kalor dan Perpindahan Kalor kelas VII di MTs Aisyiyahdiperoleh nilai rata-rata dengan kategori tidak tuntas.

3. Dari aktivitas yang diamatidenganmenggunakan model pembelajaranInquuiry Trainingdiperoleh rata-rata aktivitassiswa di kelaseksperimenselamdua kali

4. tersebut.

\section{DAFTAR PUSTAKA}

Arends, R., (2008), Learning to Teach: BelajaruntukMengajar, Pustaka Pelajar, Yogyakarta.

Prosedur Penelitian, Rineka Cipta, Jakarta. pertemuanadalah

yang berkategoricukupaktif.

4. Hasil uji hipotesis memberikan nilai $t_{\text {hitung }}=$ dan $t_{\text {tabel }}=$, dengan $\mathrm{dk}$ dan taraf signifikan menunjukkan bahwa ada perbedaan akibat pengaruh model pembelajaran inquiry training terhadap hasil belajar fisika siswa pada materi pokok kalordan perpindahan kalor di kelas VII semester II MTs Aisyiyah Medan T.P 2014/2015.

\section{Saran}

1. Untuk peneliti selanjutnya diharapkan lebih mengoptimalkan pengelolaan kelas khususnya pada saat diskusi berlangsung agar tidak terjadi kegaduhan-kegaduhan di dalam kelas.

2. Kepada siswa selanjutnya yang akan melaksanakan Model Pembelajaran Inquiry Training, sebaiknya meningkatkan kerjasama dan tanggung jawab dalam berdiskusi dan berkelompok.

3. Kepada guru yang ingin melakukan pembelajaran dengan model pembelajaran inquiry training ada baiknya memberikan motivasi terlebih dahulu kepada siswa yang akan mempresentasikan hasil karya untuk meningkatkan rasa percaya diri pada siswa

Arikunto, S., (2006), DasarDasarEvaluasiPendidikan, BumiAksara, Jakarta.

Arikunto, S.,(2009),

Djamarah, S.B. dan Aswan, Z., (2006), Strategi Belajar Mengajar, Rineka Cipta, Jakarta 
Dimyati dan Mudjiono (2009), Belajar dan Pembelajaran, Rineka Cipta, Jakarta

Hasbullah, (2005), Dasar-Dasar Ilmu Pendidikan, RajaGrafindo, Jakarta

Joyce, B., Weil, M. dan Calhoun, E., (2009), Models of Teaching: Model-Model Pengajaran, Pustaka Pelajar, Yogyakarta.

Kanginan, M., (2013), Fisikauntuk SMPKelasVII, Erlangga, Jakarta.
Slameto, (2010), BelajardanFaktorfakror yang Mempengaruhinya, RinekaCipta, Jakarta.

Sudjana, (2005), Metode Statistika, Penerbit Tarsito, Bandung.

Sukmadinata, Nana , (2003), Landasan Psikologi Pendidikan, Remaja Rosdakarya

Sanjaya, W., (2009), Strategi Pembelajaran Berorientasi Standar dan Proses Pendidikan, Penerbit Kencana Predana Media Group, Jakarta.
Marwan, Khairun Nisa. 2014. Pengaruh Model pembelajaranIquiry Training

TerhadapHasilBelajarSiswaPada MateriSuhudanKalorKelas Semester II SMA Negeri 1 BatangKuis T.P. 2013/2014.Medan : FMIPA Unimed

Rusman. 2012. Model-Model PembelajaranMengembangkanPr ofesionalisme Guru. Jakarta: PT. Raja Grafindo

Syafitri, Maya . 2014. Pengaruh Model Pembelajaran Inquiry Training Terhadap Hasil Belajar Siswa Pada Materi Kalor Kelas X Semester II SMA Negeri 1 Tanjung Pura T.P. 2013/2014. Medan : FMIPA Unimed

Sagala, S., (2009), KonsepdanMaknaPembelajaran , CV Alfabeta, Bandung.

Sadiman., (2009), Media Pendidikan, PT Raja Grafindo Persada, Jakarta.

Sardiman, (2009), Interaksi dan Motivasi Belajar Mengajar, PT Raja Grafindo Persada, Jakarta.
Trianto, (2010), Mendesain Model Pembelajaran InovatifProgresif, Kencana, Jakarta. 